\title{
Phytochemical Compounds of Cichorium intybus by Exploring its Antioxidant and Antidiabetic Activities
}

\author{
Dina Kanj ${ }^{1}$, Karim Raafat ${ }^{1, *}$, Abdalla El-Lakany ${ }^{1}$, Safaa Baydoun ${ }^{2}$, Maha Aboul-Ela ${ }^{1}$
}

\section{Dina Kanj ${ }^{1}$, Karim Raafat ${ }^{1, *}$ Abdalla El-Lakany', Safaa Baydoun², Maha Aboul-Ela'}

\section{'Department of Pharmaceutical Sciences, Faculty of Pharmacy, Beirut Arab University, Beirut 115020, LEBANON. \\ ${ }^{2}$ Research Center for Environment and Development, Beirut Arab University, Taanayel, LEBANON. \\ Correspondence \\ Dr. Karim Raafat}

Department of Pharmaceutical Sciences, Faculty of Pharmacy, Beirut Arab University (BAU), Beirut, LEBANON.

Phone no : +961 1300110

E-mail:k.raafat@bau.edu.lb

History

- Submission Date: 31-08-2018.

- Review completed: 15-11-2018;

- Accepted Date: 27-11-2018.

DOI : 10.5530/pj.2019.11.39

Article Available online

http://www.phcogj.com/v11/i2

\section{Copyright}

(C) 2019 Phcog.Net. This is an openaccess article distributed under the terms of the Creative Commons Attribution 4.0 International license

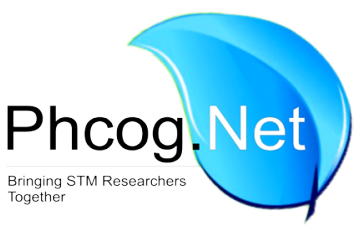

\begin{abstract}
Introduction: The current study aims to evaluate the therapeutic effect of Cichorium intybus n-hexane extract on diabetes mellitus and its antioxidant effect in vivo in alloxinated animals. Diabetic neuropathy improvement was also tested as well as insulin levels and histology of the pancreas were performed. Methods: The chromatographic standardization of $C$. intybus extract was performed using isocratic HPLC, which indicated the presence of numerous phyto-constituents. The hexane extract was studied for its effect on blood glucose levels and painful Diabetic neuropathy (DN) in diabetic mice. Hyperalgesia and mechanical-allodynia were evaluated using thermal stimuli, pain response to radiant energy experiments and a mechanical sensitivity test respectively. Subsequently, after eight weeks of being alloxinated, BGL, body weight, antioxidant activity, insulin levels and glycated hemoglobin were recorded to evaluate antidiabetic potential and the DN. Results: The administration of Cichorium intybus extract (50, 75 and $100 \mathrm{mg} / \mathrm{kg}$ ) and a combination of Cichorium intybus extract and Camellia sinensis ( $50+200 \mathrm{mg} / \mathrm{kg}$, respectively) have revealed an acute hypoglycemic effect ranging from $14.15 \%$ and $42.4 \%$. The sub-chronic anti-diabetic effect ranged from $23.41 \%$ and $44.8 \%$. They diminished hyperalgesia and tangible allodynia significantly ( $p<0.05),(n=7$ per group). The powerful neuroprotective properties might serve as potential lead-compounds for further analysis. Conclusion: The histological study and the potent antioxidant effect showed that they could assist in the management of diabetes mellitus and DN by amelioration of insulin levels and regeneration of pancreatic beta cells.
\end{abstract}

Key words: Cichorium intybus, Phytochemical analysis, Antioxidant, Serum insulin, Antidiabetic effects.

\section{INTRODUCTION}

Type 1 Diabetes mellitus (T1DM) is identified by an impairment of the secretion of insulin or insulin shortage that leads to an imbalance of glucose metabolism. DM is considered as the prime of the five main causes of death in the world. ${ }^{1}$ This is due to the lifestyle differences that result in lack of exercise and a rise in obesity. ${ }^{2}$ The most frequent cause of death among these persons is due to myocardial infarction. ${ }^{1}$

Diabetic neuropathies (DN) are the predominant chronic complications of diabetes. This varied group of circumstances affects different areas of the nervous system and presents diverse clinical signs. The early identification and proper management of neuropathy in the patient with diabetes are essential for many reasons and may be treatable by specific methods. Some of the drugs' choices exist for symptomatic diabetic neuropathy. Identification of autonomic neuropathy and being under control may ameliorate symptoms, decrease sequelae, improve quality of life and help patients in danger for injuries to their insensate feet. The diabetic state is postulated in the rise of oxidative stress. High levels of ROS have a role in the expansion of diabetic complications. The evolution of hyperglycemia can be attributed to an inequity between ROS, for instance, Hydroxyl radicals (HO), superoxide anions $\left(\mathrm{O}_{2}\right)$ and $\mathrm{H}_{2} \mathrm{O}_{2} \cdot{ }^{3-4}$

Oxidation is a natural response that includes the

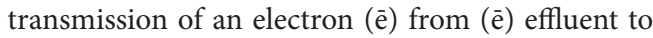
a (ē) lacking object. The term oxidizer or oxidizing agent is an electron deficient molecule. The antioxidants are produced either endogenously or are received from exogenous sources. ${ }^{5}$

Catalases are ordinary enzymes, of the antioxidant nature, that generate the change of $\mathrm{H}_{2} \mathrm{O}_{2}$ to $\mathrm{H}_{2} \mathrm{O}$ and $\mathrm{O}_{2}$. Catalases exist everywhere in aerobic life, including almost all mammalian tissues. The predominant enzyme action resides in the liver and erythrocytes. Catalases, which mostly reside in peroxisomes in cells and mitochondria as both soluble and membrane-bound forms. ${ }^{6}$

Cichorium intybus (C. intybus or CI) took its name from the Latin term, "Cichorium" signifying field and "intybus" is partially the result of the Latin term, "to cut". C. intybus L., being of the Asteraceae, is
Cite this article: Kanj D, Raafat K, El-Lakany A, Baydoun S, Aboul-Ela M. Phytochemical Compounds Of Cichorium intybus by Exploring its Antioxidant and Antidiabetic Activities. Pharmacog J. 2019;11(2):248-57. 
a bushy biennial herb that may be utilized in the food industry. ${ }^{8-9}$ It is indigenous to Europe and Asia. ${ }^{10} \mathrm{C}$. intybus can reach $170 \mathrm{~cm}$ in height and the roots are shaped as spindle. ${ }^{11}$ The herb may germinate in a wild manner in its ordinary territory and/or river banks. Flowering periods last from June to October. ${ }^{10}$ C. intybus L. or "Hendibeh" is eaten in Lebanon, the Middle East and in other countries. ${ }^{9}$ Camellia sinensis (C. sinensis) is also commended for having hypoglycemic effects as it has proven to have some potential in preventing insulin resistance. ${ }^{12}$

A study conducted in 2007, by Pushparaj et al. ${ }^{13}$ was performed to examine the activity of $C$. intybus ethanolic extract on hyperglycemia. This extract was used as a conventional drug for the management of DM. The result showed that the extract might improve DM. There is no study performed on the DN effect of the $C$. intybus hexane extracts.

Consequently, the study aims to explore not only the hypoglycemic effect of C. intybus, but also the possible antioxidant activity, improvement of $\mathrm{DN}$, amelioration of insulin levels and enhancement of pancreatic beta cells.

\section{MATERIALS AND METHODS}

\section{Plants materials}

Total plant fragments of Cichorium intybus were assimilated from the RCED and identified by Prof. Nelly Arnold. The parts used are the roots which were dried and pulverized. The oil was extracted with hexane. No essential oil (EO) yield was obtained from the aerial parts.

\section{Preparing the Cichorium intybus Extract}

The extract was readied by adding $100 \mathrm{ml}$ of hexane. The mixture was put in the sonicator at a temperature of $56^{\circ} \mathrm{C}$ for $2 \mathrm{~h}$. The extract was filtered by Whatman filter paper. ${ }^{14}$ The solvent was evaporated using the rotary evaporator to one-third of its starting volume. The collected final extract was kept in the freezer at $-26^{\circ} \mathrm{C}$ for later use.

\section{Animals for in vivo studies}

The animals used for in vivo studies were Male Swiss-Webster mice, aging between 12 to 16 weeks and weighing between 25 to $32 \mathrm{~g}$ provided by the Animal House, Faculty of Pharmacy, Beirut Arab University. The mice were kept in an adaptation environment prior to the experiment. The mice were reserved in distinct plexi-boxes at an ambient climate $\left(22 \pm 1^{\circ} \mathrm{C}\right)$ and a light/dark rotation of $12 \mathrm{~h}$ each. The mice were given standard pellets of proteins (20), fats (5) and multivitamins (1) to consume and had free access to water. The fasting of the mice was made $16 \mathrm{hrs}$ prior to the experiment; the mice were prevented of the feeding pellets but they had free access to water. The mice that were subject to experimentation were treated with care (Table 1), conferring to the regulations of the Lebanese Ministry of Higher Education and the animal experiment legislation and with the approval code (2016A-0040-P-M-0144) of the Institutional Review Board (IRB) of Beirut Arab University.

\section{Aqueous extract of Camellia sinensis}

Five pills of $450 \mathrm{mg}$ of Camellia sinensis (Green Tea powder Thompson) were soaked in $22.5 \mathrm{ml}$ hot water for $15 \mathrm{~min}$. The Filtrate was done by Whatman filter paper and kept in the fridge for later use.

\section{Preparing the Insulin stock and standard solutions}

The stock insulin was prepared by adding $0.01 \mathrm{M} \mathrm{HCl}$ at a concentration of $100 \mu \mathrm{g} / \mathrm{mL}$. Using diluted stock insulin solution, the standards were prepared at $(5,10$ and $25 \mu \mathrm{g} / \mathrm{mL}){ }^{15}$

\section{Extraction procedure}

A blank plasma at $0.2 \mathrm{~mL}$ was transferred to a $12 \mathrm{~mL}$ centrifuge with $1 \mathrm{~mL}$ of phosphate buffer ( $\mathrm{pH}$ 7.4) and swirled the solutions for a short time. One $\mathrm{mL}$ of $\mathrm{CH}_{2} \mathrm{Cl}_{2}$ was placed into the tube and swirled for $1 \mathrm{~min}$. The tube was swirled for 3 mins at 2,000 x g. The organic phase was moved to a $5 \mathrm{~mL}$ tube. I added $0.15 \mathrm{~mL}$ of $0.05 \mathrm{M} \mathrm{HCl}$ into this tube and swirled it for $1 \mathrm{~min}$. The clear liquid was then moved to another tube and left to evaporate at ambient climate. I rebuilt the deposit by putting it over $1 \mathrm{~mL}$ of $0.01 \mathrm{M} \mathrm{HCl}$. The solution was filtrated through a syringe filter vessel of $0.45 \mu \mathrm{m}$. A sample of $20 \mu \mathrm{L}$ was analyzed by placing it into the automatic sample injector of HPLC system. ${ }^{16}$

\section{Diabetes mellitus induction}

DM is experimentally induced by giving alloxan monohydrate (SigmaAldrich, Germany) freshly prepared through intraperitoneal (IP) injection to mice. Alloxan was dissolved in saline solution (0.9\%) and was delivered every other day (three times a week) at a dose of $180 \mathrm{mg} / \mathrm{kg}$ of body weight (BW).

\section{TLC analysis of Cichorium intybus extract}

The stationary phase of silica gel was prepared. Using TLC spotting capillaries tubes 3 different spots were put. $\mathrm{C} 1=2$ drops of $\mathrm{CI} \mathrm{Ex}, \mathrm{C} 2=5$ drops of $\mathrm{CI}$ extract and $\mathrm{C} 3=10$ drops of CI Ex. $10 \%$ ethanolic $\mathrm{H}_{2} \mathrm{SO}_{4}$ reagent was prepared for the detection method, the plate was then put in the oven to dry at a temperature of $115^{\circ} \mathrm{C}$ for $15 \mathrm{~min}$. The detection was in the UV light $365 \mathrm{~nm} .{ }^{17}$

\section{HPLC analysis of Cichorium intybus extract}

High performance liquid chromatography (HPLC) is a highly improved form of liquid chromatography. A faster technique where the liquid is forced through a column under very high pressures up to 400 atmospheres. HPLCWaters717 plus Autosampler Multi $\lambda$ fluorescence detector with Waters 2487 Dual $\lambda$ Absorbance detector is the apparatus used. HPLC method was adapted from the method mentioned by Sakamoto, et al. ${ }^{18}$

HPLC analysis (Isocratic elution with $\mathrm{MeOH} / \mathrm{H}_{2} \mathrm{O} 9: 1 ; \lambda=265 \mathrm{~nm}$; flow $9.5 \mathrm{~mL} / \mathrm{min}$; injection volume $=20 \mu \mathrm{l}$; and the runtime $=40 \mathrm{~min}$ ). The $\mathrm{MeOH} / \mathrm{H}_{2} \mathrm{O}$ was prepared by adding $45 \mathrm{ml} \mathrm{MeOH}$ to $5 \mathrm{ml}$ DDW. The sample stock (1) was prepared by weighing $1 \mathrm{mg}$ of the $C$. intybus residue which was added to $1 \mathrm{ml}$ of ACN, from stock (1) $200 \mu \mathrm{l}$ was added to $800 \mu \mathrm{l} \mathrm{ACN}$.

\section{Determination of blood glucose levels}

After three days of alloxinating the mice, the BGL of all the animals was measured, using ACCU-CHEK Performa ${ }^{\mathrm{me}}$ Test Meter (Roche, USA) to confirm hyperglycemia. The blood samples were taken carefully from the animal's tail. A solution of 5\% Glucose was administered as drinking water to the mice. The BGL were expressed as $\mathrm{mg} / \mathrm{dl}$. The mice with BGL higher than $200 \mathrm{mg} / \mathrm{dl}$ were considered as hyperglycemic and were used in the experimental research. ${ }^{16}$

\section{Management of diabetic neuropathy (DN) Hot plate (HP) test}

$\mathrm{HP}$ analgesia meter (Ugo Basile, Italy) was used for valuation of DN. Each mouse from the six groups treated with C. intybus extract alone and in association with $C$. sinensis extract at different doses was placed alone in the hot plate at a temperature of $50 \pm 0.1^{\circ} \mathrm{C}$. Response time to jumping or hind paw licking was observed utilizing a timer. To prevent tissue harm, 30 secs of shut-off time was selected. ${ }^{19}$

\section{Tail flick (TF) test}

TF apparatus (Hugo-Sachs-Bektronik, Germany) was used to assess DN. The tail flick test is a pain response test for animals. It is used to measure the usefulness of analgesics, by observing heat response. This meter measures a mouse's reaction time to radiant energy, from a light source. The energy of the light source can be adjusted. The light intensity was set to 8 ; a cut-off time of $10.00 \pm 0.50 \mathrm{sec}$ was set in order to prevent tissue damage. ${ }^{20}$ 
Kanj, et al:: Cichorium intybus Phytochemical and Biological Investigations

Table 1: Study scheme.

\begin{tabular}{|c|c|c|c|}
\hline \multicolumn{4}{|c|}{ A. Diabetic } \\
\hline Group & $\mathrm{n}=$ & Name & Dosage at $0 \mathrm{~h}, 0.5 \mathrm{~h}, 2 \mathrm{~h}$ and $6 \mathrm{~h}$ \\
\hline I & 7 & NC & Saline $(0.9 \% \mathrm{NaCl})$ \\
\hline III & 7 & DC & Saline $(0.9 \% \mathrm{NaCl})$ \\
\hline IV & 7 & $\mathrm{DC}+\mathrm{CI} 50$ & CI extract $50 \mu \mathrm{l}$ \\
\hline V & 7 & $\mathrm{DC}+\mathrm{CI} 75$ & CI extract $75 \mu \mathrm{l}$ \\
\hline VI & 7 & $\mathrm{DC}+\mathrm{CI} 100$ & CI extract $100 \mu \mathrm{l}$ \\
\hline VII & 7 & $\begin{array}{c}\mathrm{DC}+\mathrm{CI} 50+\mathrm{CS} \\
200\end{array}$ & $\begin{array}{c}\text { CI extract } 50 \mu \mathrm{l}+\mathrm{C} \text {. sinensis extract } \\
200 \mu\end{array}$ \\
\hline \multicolumn{4}{|c|}{ B. Subchronic effect } \\
\hline Group & $\mathrm{n}=$ & Name & $\begin{array}{c}\text { Dosage: } 3 \text { times a week (once a day) } \\
\text { for } 8 \text { days }\end{array}$ \\
\hline VIII & 7 & $\mathrm{NC}$ & Saline $(0.9 \% \mathrm{NaCl})$ \\
\hline IX & 7 & DC & Saline $(0.9 \% \mathrm{NaCl})$ \\
\hline $\mathrm{X}$ & 7 & $\mathrm{DC}+\mathrm{CI} 50$ & CI extract $50 \mu \mathrm{l}$ \\
\hline XI & 7 & $\mathrm{DC}+\mathrm{CI} 75$ & $\mathrm{CI}$ extract $75 \mu \mathrm{l}$ \\
\hline XII & 7 & $\mathrm{DC}+\mathrm{CI} 100$ & CI extract $100 \mu \mathrm{l}$ \\
\hline XIII & 7 & $\begin{array}{c}\mathrm{DC}+\mathrm{CI} 50+\mathrm{CS} \\
200\end{array}$ & $\begin{array}{c}\text { CI extract } 50 \mu \mathrm{l}+\mathrm{C} \text {. sinensis extract } \\
200 \mu\end{array}$ \\
\hline \multicolumn{4}{|c|}{ B. Diabetic neuropathy } \\
\hline Group & $\mathrm{n}=$ & Name & $\begin{array}{c}\text { Dosage: } 3 \text { times a week (once a day) } \\
\text { for } 8 \text { weeks }\end{array}$ \\
\hline XIV & 7 & NC & Saline $(0.9 \% \mathrm{NaCl})$ \\
\hline $\mathrm{XV}$ & 7 & DC & Saline $(0.9 \% \mathrm{NaCl})$ \\
\hline XVI & 7 & $\mathrm{DC}+\mathrm{CI} 50$ & CI extract $50 \mu \mathrm{l}$ \\
\hline XVII & 7 & $\mathrm{DC}+\mathrm{CI} 75$ & CI extract $75 \mu \mathrm{l}$ \\
\hline XVIII & 7 & $\mathrm{DC}+\mathrm{CI} 100$ & CI extract $100 \mu \mathrm{l}$ \\
\hline XIX & 7 & $\begin{array}{c}\mathrm{DC}+\mathrm{CI} 50+\mathrm{CS} \\
200\end{array}$ & $\begin{array}{c}\text { CI extract } 50 \mu \mathrm{l}+\mathrm{C} \text {. sinensis extract } \\
200 \mu \mathrm{l}\end{array}$ \\
\hline
\end{tabular}

\section{Von Frey filaments (VFF) test}

The use of Von Frey filaments (OptiHair TM, MarstockNervtest ${ }^{\mathrm{Tx}}$, Germany) leads to the assessment of a rodent's sensitivity to a mechanical stimulus (tactile allodynia). Fibers with rising calibration (0.5 - 45.3g $\pm 10 \%)$ were inserted at 90 degree angle through the mesh to poke the animal's hind paw and using an up-down method. A power just enough to slightly bow the fiber that was inserted for $5 \mathrm{sec}$. Affirmative reactions for the animal include abrupt withdrawing or licking or shaking the paw. ${ }^{20}$

\section{Measuring glycated hemoglobin profile}

In vitro analysis of the glycated hemoglobin (HbAlc) concentrations were measured in mice blood by pricking the tail, utilizing (Analyticon, Analyticon Biotechnologies AG, Am Munsterberg, Germany) test kit, of the different six groups, mentioned previously after 8 weeks of the onset of the drugs' administrations.

\section{Effects of $C$. intybus and $C$. sinensis extracts on diabetic neuropathy}

The potential effect of $C$. intybus extract alone and in association with C. sinensis extract on DN was studied. The six groups of mice were tested. After 4-weeks of DM induction and for 8 consecutive weeks at an interval of one week, DN achievement rate and their neurological results were verified by:
In vivo antioxidant effect of $C$. intybus alone and in association with $C$. sinensis extract

To prove that $C$. intybus and $C$. sinensis extracts have an antioxidant effect, serum catalase activity was studied. After 8-weeks of the drugs' administrations, $50 \mu \mathrm{l}$ of blood samples were taken from the mice's tails from the six groups. The samples were swirled and the serum was collected. CAT was established by an adapted method described by Yasmineh, et al. ${ }^{21}$ Serum was added to the phosphate buffer freshly prepared. The reaction took place as soon as $\mathrm{H}_{2} \mathrm{O}_{2}$ is added. The rate of the reaction was established by observing the reduction in the absorbance of $\mathrm{H}_{2} \mathrm{O}_{2}$ at $240 \mathrm{~nm}$ for $5 \mathrm{~min}$ by a UV NIS spectrophotometer (SP-3000 plus, Optima, Japan).

\section{Statistical Analysis}

All data is presented as a sum of averages \pm SEM. Statistical variances between the test group and control group were tested through a one-way analysis of variance (ANOVA) entailed by the Student-Newman-Keuls test utilizing the "OriginPro" statistic computer software. A variance in the mean values of $p<0.05$ was accepted to be statistically significant.

\section{RESULTS}

\section{Pharmacognostic description}

C. intybus root consisted of the fleshy deep taproot, deep, branched, up to seventy-five $\mathrm{cm}$ long, with a milky-sap.

\section{Chromatographic analysis of the oil extract of C. intybus}

Constituents' identification contributes in more understanding of C. intybus importance. Thus, chromatographic analysis of the oil extract of $C$. intybus was done.

\section{Thin layer chromatography}

C. intybus hexane extract has undergone a TLC analysis. The chromatographic standardization, using TLC, indicated the presence of fructose, glucose and sucrose, ketose, nystose and the inulin type DP fructans: DP4, DP5 and DP6 (Figure S. 1).

\section{Chromatographic standardization of Cichorium intybus}

The chromatographic standardization, using isocratic HPLC, indicated that the most active compounds of $C$. intybus extract fraction major peaks were in the retention time range from 10 to $35 \mathrm{~min}$. The six peaks found to represent a total percentage of $92.22 \%$. The major compounds found in $C$. intybus extract are Chicoric acid at a high percentage (64.70\%), Isochlorogenic acid A/B/C (8.90\%), Dicaffeoylquinic acid (6.87\%), Chlorogenic acid (4.81\%), Esculetin (3.54\%), Caffeic acid $(3.40 \%)$ (Figure 1 ). The major compounds found in C. intybus extract are in the (Table 2).

\section{Chromatographic standardization of Insulin}

The chromatographic standardization of Insulin using an isocratic HPLC, (Isocratic elution with $\mathrm{ACN} / \mathrm{Na}_{2} \mathrm{SO}_{4}(0.2 \mathrm{M}) 25: 75 ; \lambda=214 \mathrm{~nm}$; flow $1.2 \mathrm{~mL} / \mathrm{min}$; injection volume $=20 \mu \mathrm{l}$; and the runtime $=30$ minutes), indicated that the active compounds of Insulin fractions major peaks were in the retention time range from 10 to $25 \mathrm{~min}^{22}$ (Figure S. 2).

\section{Acute antidiabetic effect of the $C$. intybus and $C$. sinensis extracts in alloxan-induced diabetic mice}

The acute anti-diabetic result of numerous doses of $C$. intybus extract (50 $\mu \mathrm{l}, 75 \mu \mathrm{l}$ and $100 \mu \mathrm{l}$ ) alone and in combination with C. sinensis at doses $(50 \mu \mathrm{l}+200 \mu \mathrm{l}$, respectively) in induced diabetic mice is summarized in the (Table 3) CI $50=C$. intybus extract $50 \mu \mathrm{l}$, CI $75=C$. intybus extract $75 \mu \mathrm{l}$, CI $100=C$. intybus extract $100 \mu \mathrm{l}$, CI $50+$ CS $200=C$. intybus extract $50 \mu \mathrm{l}+C$. sinensis extract $200 \mu \mathrm{l}$. The administration of $C$. intybus extract showed, at the 6 hours of the first day, a decrease in the percentage 


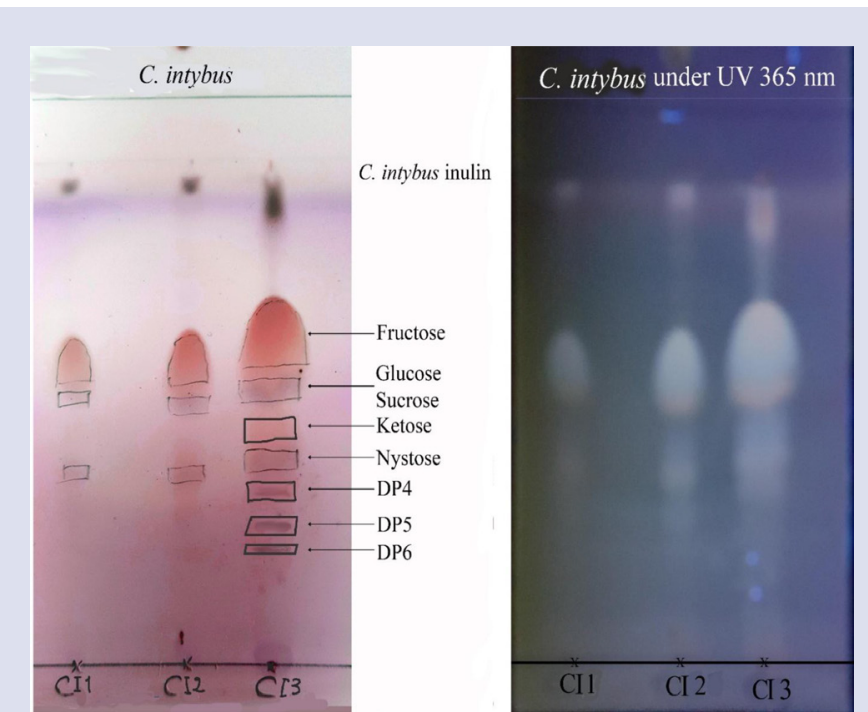

Figure S1: $\mathrm{C} 1=2$ drops of $\mathrm{Cl}$ extract, $\mathrm{C} 2=5$ drops drops of $\mathrm{Cl}$ extract and $\mathrm{C} 3=10$ drops drops of $\mathrm{Cl}$ extract. $10 \%$ ethanolic $\mathrm{H}_{2} \mathrm{SO}_{4}$ reagent was prepared for the detection method, the plate was then put in the oven to dry at a temperature of $115^{\circ} \mathrm{C}$ for 15 minutes. The detection was in the UV light $365 \mathrm{~nm}$

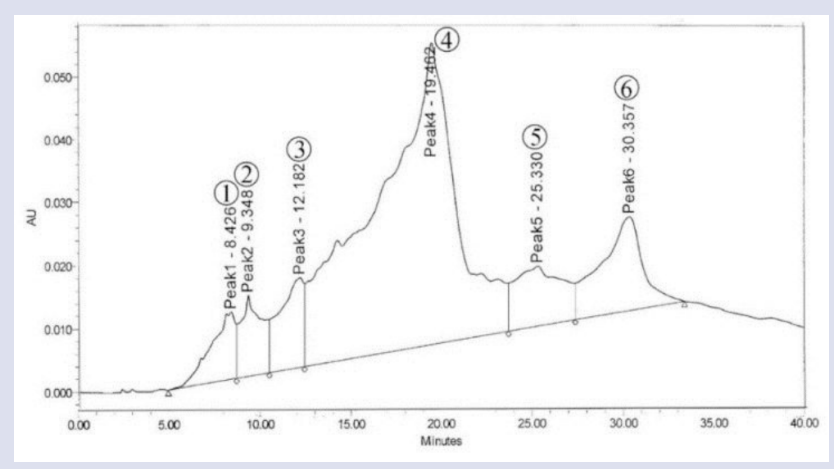

Figure 1: HPLC chromatogram of $C$. intybus using an isocratic HPLC (Isocratic elution with $\mathrm{MeOH} / \mathrm{H}_{2} \mathrm{O} 9: 1 ; \lambda=265 \mathrm{~nm}$; flow $9.5 \mathrm{~mL} / \mathrm{min}$; injection volume $=20 \mu \mathrm{l}$; and the run time $=40 \mathrm{~min}$ ).

of BGL when compared to DC. The percentage of BGL decrease for the dose CI extract $50 \mu \mathrm{l}$ was $14.15 \%$, for the dose of CI extract $75 \mu \mathrm{l}$ was $19.69 \%$, for the dose of CI extract $100 \mu \mathrm{l}$ was $42.4 \%$ and finally for the dose of CI extract $50 \mu \mathrm{l}+\mathrm{CS} 200 \mu \mathrm{l}$ was $35.19 \%$ when compared to DC. (Table 3).

\section{Subchronic effect of the C. intybus and C. sinensis extracts in alloxan- induced diabetic mice}

The Sub-chronic anti-diabetic activity, of several dosages of $C$. intybus extract $(50 \mu \mathrm{l}, 75 \mu \mathrm{l}$ and $100 \mu \mathrm{l})$ alone and in combination with $C$. sinensis at doses $(50 \mu \mathrm{l}+200 \mu \mathrm{l}$, respectively) in hyperglycemic mice, is summarized in the (Table 4). CI $50=C$. intybus extract $50 \mu \mathrm{l}$, CI $75=C$. intybus extract $75 \mu \mathrm{l}$, CI $100=C$. intybus extract $100 \mu \mathrm{l}$, CI $50+$ CS $200=C$. intybus extract $50 \mu \mathrm{l}+C$. sinensis extract $200 \mu \mathrm{l}$. The administration of C. intybus extract showed, at the $8^{\text {th }}$ day, a decrease in the percentage of BGL when compared to DC. The percentage of BGL decrease for the dose CI extract $50 \mu \mathrm{l}$ was $23.41 \%$, for the dose of CI extract $75 \mu \mathrm{l}$ was

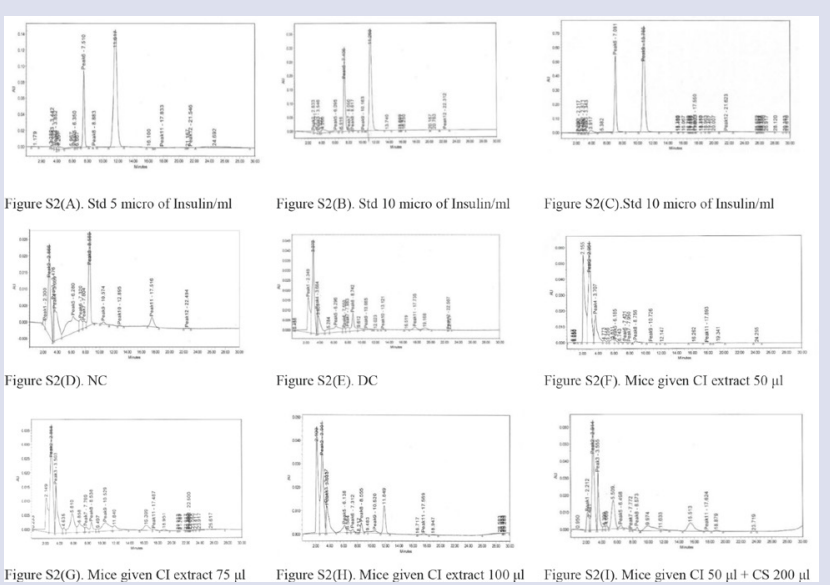

Figure S2. Represent Chromatographic standardization of Insulin using an isocratic HPLC (Isocratic elution with $\mathrm{ACN} / \mathrm{Na}_{2} \mathrm{SO}_{4}(0.2 \mathrm{M}) 25: 75 ; \lambda$ $=214 \mathrm{~nm}$; flow $1.2 \mathrm{~mL} / \mathrm{min}$; injection volume $=20 \mu \mathrm{l}$; and the run time $=30 \mathrm{~min}$ ).

Table 2: Identification of the major compounds found in C. intybus extract by HPLC.

\begin{tabular}{cccc}
\hline $\begin{array}{c}\text { Peak } \\
\text { number }\end{array}$ & RT $(\mathbf{m i n})$ & Identification & $\%$ \\
\hline 1 & 8.426 & Caftaric acid & 3.40 \\
2 & 9.348 & Aesculin & 3.54 \\
3 & 12.182 & Chlorogenic acid & 4.81 \\
4 & 19.462 & Chicoric acid & 64.70 \\
5 & 25.330 & Dicaffeoylquinic acid & 6.87 \\
6 & 30.357 & Isochlorogenic acid A/B/C & 8.90 \\
\hline
\end{tabular}

Table 3: Acute antidiabetic activity of $C$. intybus extract on BGL in alloxan-induced diabetic mice.

\begin{tabular}{ccccc}
\hline \multirow{2}{*}{$\begin{array}{c}\text { Groups/ } \\
\text { Day }\end{array}$} & \multicolumn{4}{c}{ Mean of BGL \pm S.E.M (mg/dl) } \\
\cline { 2 - 5 } & $0 \mathrm{hr}$ & $0.5 \mathrm{hr}$ & $2 \mathrm{hr}$ & $6 \mathrm{hr}$ \\
\hline $\mathrm{NC}$ & $137.50 \pm 1.50$ & $131.00 \pm 1.00$ & $111.00 \pm 1.00$ & $133.00 \pm 3.00$ \\
$\mathrm{DC}^{\mathrm{a}}$ & $198.50 \pm 1.50$ & $160.00 \pm 2.00$ & $173.50 \pm 4.50$ & $208.50 \pm 5.50^{* * *}$ \\
$\mathrm{CI}_{50} 0^{\mathrm{b}}$ & $183.00 \pm 22.00$ & $148.00 \pm 1.00$ & $157.50 \pm 1.50$ & $155.00 \pm 21.00^{*}$ \\
$\mathrm{CI}^{\mathrm{b}} 5^{\mathrm{b}}$ & $180.00 \pm 13.00$ & $132.00 \pm 5.00$ & $119.50 \pm 1.50$ & $143.00 \pm 12.00^{* *}$ \\
$\mathrm{CI} 100^{\mathrm{b}}$ & $209.00 \pm 41.00$ & $121.50 \pm 1.50$ & $103.00 \pm 3.00$ & $127.00 \pm 17.00^{* *}$ \\
$\mathrm{CI} 50+\mathrm{CS}$ & $199.50 \pm 16.500$ & $160.00 \pm 5.00$ & $133.50 \pm 1.50$ & $128.50 \pm 11.50^{* *}$ \\
$200^{\mathrm{b}}$ & & & & \\
\hline
\end{tabular}

“*” means $p<0.05$, “**” means $p<0.01$, “***” means $p<0.001$. ${ }^{a}$ Compared to NC, ${ }^{b}$ Compared to DC. $\mathrm{n}=7$ mice/group.

$25.39 \%$, for the dose of CI extract $100 \mu \mathrm{l}$ was $44.8 \%$ and finally for the dose of CI extract $50 \mu \mathrm{l}+\mathrm{CS} 200 \mu \mathrm{l}$ was $35.19 \%$ when compared to DC. During the 8 days of the drugs administrations of the hyperglycemic mice, with C. intybus extract $(50 \mu \mathrm{l}, 75 \mu \mathrm{l}$ and $100 \mu \mathrm{l})$ alone and in combination with $C$. sinensis at doses $(50 \mu \mathrm{l}+200 \mu \mathrm{l}$, respectively), the weights of the mice were also observed for changes (Table 5). The administration of $C$. intybus extract showed, at the $8^{\text {th }}$ day, an increase in the percentage of BW when compared to DC. The percentage of BW increase for the 
Table 4: Subchronic effect of C. intybus extract on BGL of alloxinated mice.

\begin{tabular}{ccccc}
\hline Groups/ & \multicolumn{4}{c}{ Mean BGL \pm S.E.M $(\mathrm{mg} / \mathrm{dl})$} \\
\cline { 2 - 5 } Day & $1^{\text {st }}$ day & $3^{\text {rd }}$ day & $5^{\text {th }}$ day & $8^{\text {th }}$ day \\
\hline NC & $128.50 \pm 8.50$ & $134.00 \pm 7.00$ & $135.00 \pm 5.00$ & $132.00 \pm 1.00$ \\
DC $^{\text {a }}$ & $207.00 \pm 7.00$ & $200.00 \pm 3.00$ & $165.50 \pm 3.50$ & $210.00 \pm 18.00^{* *}$ \\
${\text { CI } 50^{\mathrm{b}}}^{*}$ & $180.50 \pm 4.50$ & $137.50 \pm 3.50$ & $155.50 \pm 9.50$ & $143.00 \pm 14.00^{*}$ \\
$\mathrm{CI}^{*} 5^{\mathrm{b}}$ & $144.50 \pm 18.50$ & $152.50 \pm 15.50$ & $120.00 \pm 8.00$ & $135.00 \pm 9.00^{*}$ \\
$\mathrm{CI} 100^{\mathrm{b}}$ & $133.50 \pm 76.50$ & $142.50 \pm 5.50$ & $149.00 \pm 18.00$ & $123 \pm 15.00^{*}$ \\
$\mathrm{CI} 50+$ & $146.50 \pm 38.50$ & $151.50 \pm 0.50$ & $150.50 \pm 21.50$ & $121.00 \pm 10.00^{*}$ \\
CS 200 & & & & \\
\hline
\end{tabular}

“*” means $p<0.05$, “**” means $p<0.01$. ${ }^{\text {a C}}$ Compared to NC, ${ }^{\text {b }}$ Compared to DC. $\mathrm{n}=7$ mice/group.

Table 5: Subchronic effect of C. intybus extract on BW in alloxinated animals.

\begin{tabular}{ccccc}
\hline \multirow{2}{*}{ Groups } & \multicolumn{4}{c}{ Mean BW \pm S.E.M (g) } \\
\cline { 2 - 5 } & $1^{\text {st }}$ day & $3^{\text {rd }}$ day & $5^{\text {th }}$ day & $8^{\text {th }}$ day \\
\hline NC & $30.00 \pm 0.05$ & $27.70 \pm 0.20$ & $29.05 \pm 0.55$ & $30.05 \pm 0.05$ \\
DC $^{\text {a }}$ & $30.05 \pm 0.15$ & $29.25 \pm 0.25$ & $29.75 \pm 0.75$ & $28.45 \pm 0.45^{* *}$ \\
CI 50 & $29.15 \pm 0.05$ & $27.77 \pm 1.23$ & $28.50 \pm 0.40$ & $29.65 \pm 0.05^{*}$ \\
CI 75 & $28.30 \pm 0.70$ & $29.55 \pm 0.05$ & $29.70 \pm 0.30$ & $30.35 \pm 0.05^{*}$ \\
CI $100^{\text {b }}$ & $27.20 \pm 0.30$ & $29.30 \pm 0.10$ & $31.00 \pm 0.50$ & $31.50 \pm 0.50^{* *}$ \\
CI 50 + CS & $27.75 \pm 0.75$ & $30.90 \pm 0.40$ & $31.90 \pm 0.60$ & $31.90 \pm 0.60^{* *}$ \\
$200^{\text {b }}$ & & &
\end{tabular}

“*” means $p<0.05$, “**” means $p<0.01$. a Compared to NC, ${ }^{\text {b }}$ Compared to DC. $\mathrm{n}=7 \mathrm{mice} /$ group.

dose $\mathrm{CI}$ extract $50 \mu \mathrm{l}$ was $6 \%$, for the dose of $\mathrm{CI}$ extract $75 \mu \mathrm{l}$ was $8.5 \%$, for the dose of CI extract $100 \mu \mathrm{l}$ was $14.2 \%$ and finally for the dose of CI extract $50 \mu \mathrm{l}+\mathrm{CS} 200 \mu \mathrm{l}$ was $15 \%$ when compared to DC.

\section{Measurement of Glycated Hemoglobin profile}

After 8 weeks of starting the drugs' administrations, HbAlc was measured for hyperglycemic mice. Four different concentration of $C$. intybus extract (50 $\mu \mathrm{l}, 75 \mu \mathrm{l}$ and $100 \mu \mathrm{l}$ ) and a combination of C. intybus extract with C. sinensis extract $(50 \mu \mathrm{l}+200 \mu \mathrm{l})$ were used. For each group, HbAlc was measured to indicate the long-term hyperglycemia in mice.

The Figure 2 Shows that the $\mathrm{NC}$ of $\mathrm{HbA} 1 \mathrm{c}$ has a normal result $(4.5 \% \pm 0.23)$, whereas in DC HbAlc was $(8.5 \% \pm 0.43)$. The percentage of the result for the dose CI extract $50 \mu \mathrm{l}$ was $(7.3 \% \pm 0.37)$, for the dose of CI extract $75 \mu \mathrm{l}$ was $(6.9 \% \pm 0.35)$, for the dose of CI extract $100 \mu \mathrm{l}$ was $(6.27 \% \pm 0.32)$ and finally for the dose of CI extract $50 \mu \mathrm{l}+\mathrm{CS} 200 \mu \mathrm{l}$ was $(6.5 \% \pm 0.33)$. These doses were effective and maintained the HbA1C within the "good control" range and the highest effects were with the extract of CI at the dose $100 \mu \mathrm{l}$ and the combination of the extract of CI and CS at doses of $50 \mu \mathrm{l}+200 \mu \mathrm{l}$, respectively, when compared to DC.

\section{Measurement of Insulin profile}

After 8 weeks of starting the drugs' administrations, Insulin was measured for alloxan-induced diabetic mice. Four different concentration of C. intybus extract ( $50 \mu \mathrm{l}, 75 \mu \mathrm{land} 100 \mu \mathrm{l})$ and a combination of $C$. intybus extract with $C$. sinensis extract $(50 \mu \mathrm{l}+200 \mu \mathrm{l})$ were delivered.

The Figure 3 shows that the NC of Insulin is in the normal range (9.61\% $\pm 0.48)$, whereas in DC it was $(0.87 \% \pm 0.13)$ and for the dose CI extract $50 \mu \mathrm{l}$ was $(1.87 \% \pm 0.17)$, for the dose of $\mathrm{CI}$ extract $75 \mu \mathrm{l}$ was $(3.22 \% \pm$ $0.16)$, for the dose of $\mathrm{CI}$ extract $100 \mu \mathrm{l}$ was $(9.06 \% \pm 0.3)$ and finally for

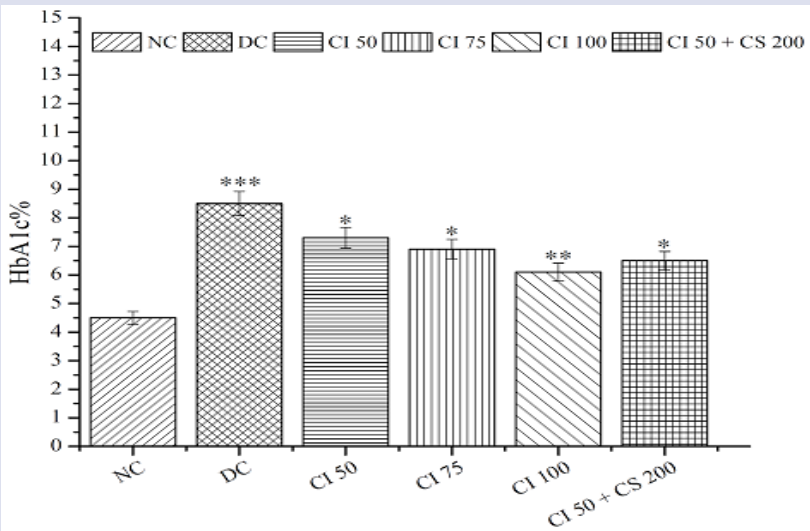

Figure 2: Measurement of glycated hemoglobin profile in alloxinated animals of $C$. intybus and $C$. sinensis extracts. $\mathrm{NC}=$ Normal control, $\mathrm{DC}=$ Diabetic control, $\mathrm{Cl} 50=\mathrm{C}$. intybus extract $50 \mu \mathrm{l}, \mathrm{Cl} 75=\mathrm{C}$. intybus extract $75 \mu \mathrm{l}, \mathrm{Cl} 100=C$. intybus extract $100 \mu \mathrm{l}, \mathrm{Cl} 50+\mathrm{CS} 200=$ C. intybus extract $50 \mu \mathrm{l}+\mathrm{C}$. sinensis extract $200 \mu \mathrm{l}$. Data are expressed in mean \pm S.E.M. (standard error of the mean). "**" means $p<0.05$, "***" means $p<0.01,{ }^{\prime \prime * * * " ~ m e a n s ~} p<0.001 . \mathrm{n}=7$ mice/group.

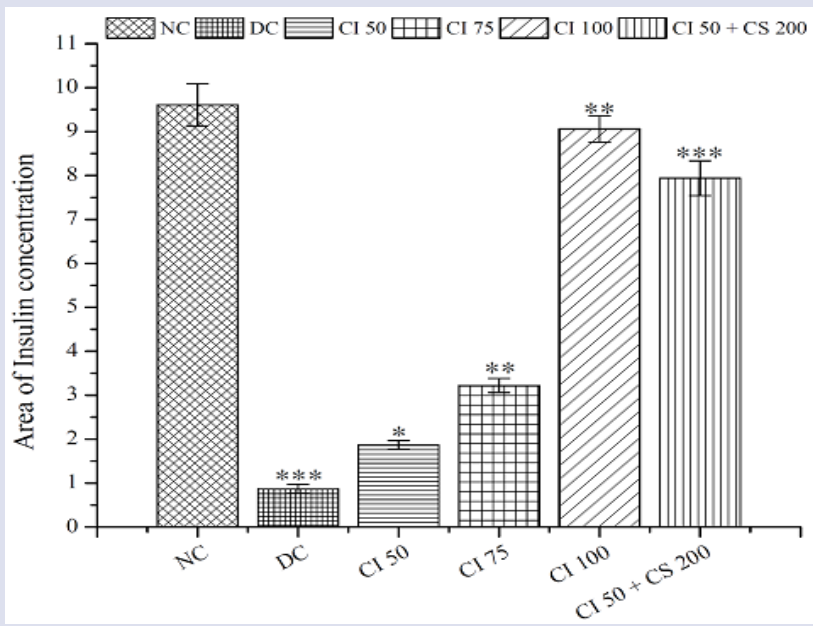

Figure 3: Measurement of Insulin profile in alloxinated animals of C. intybus and C. sinensis extracts. NC $=$ Normal control, DC $=$ Diabetic control, Cl $50=C$. intybus extract $50 \mu \mathrm{l}, \mathrm{Cl} 75=C$. intybus extract $75 \mu \mathrm{l}$, $\mathrm{Cl} 100=C$. intybus extract $100 \mu \mathrm{l}, \mathrm{Cl} 50+\mathrm{CS} 200=C$. intybus extract $50 \mu \mathrm{l}+\mathrm{C}$. sinensis extract $200 \mu \mathrm{l}$. Data are expressed in mean \pm S.E.M (standard error of the mean). " $* * *$ means $p<0.01,{ }^{\prime \prime * * * * " ~ m e a n s ~} p<0.001$. $\mathrm{n}=7$ mice/group.

the dose of CI extract $50 \mu \mathrm{l}+\mathrm{CS} 200 \mu \mathrm{l}$ was $(7.94 \% \pm 0.39)$. The rise of insulin rate was a dose-dependent. The highest Insulin rates were with the CI extract $100 \mu \mathrm{l}$ and the combination CI and CS extract at doses of $50 \mu l+200 \mu l$, respectively, when compared to DC.

\section{Analysis of antioxidant activity}

CAT serum's levels of each mice group were measured, eight weeks after the onset of the drugs' administration for alloxan-induced diabetic mice, to assess the antioxidant activity of $C$. intybus. The results, summarized in Figure 4, show that the diabetic animals were monitored by changes 


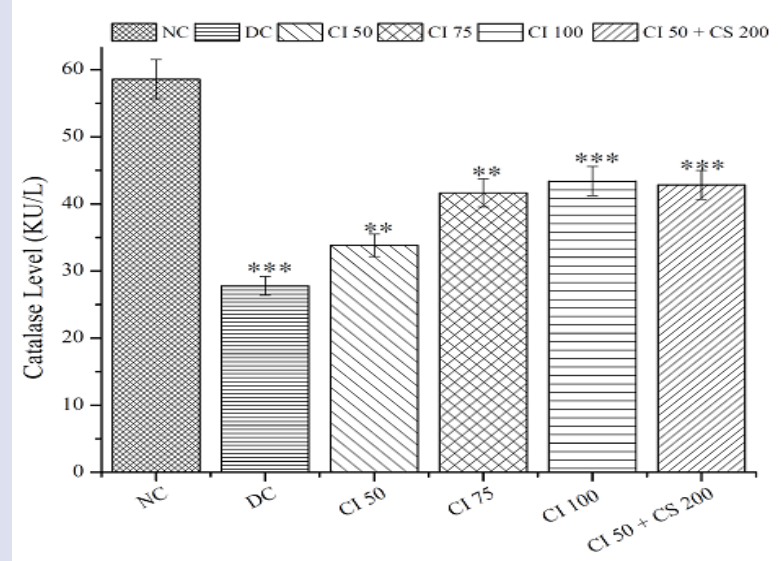

Figure 4: In vivo analysis of the antioxidant effect of $C$. intybus and C. sinensis extracts. NC $=$ Normal control, $\mathrm{DC}=$ Diabetic control, $\mathrm{Cl} 50=C$. intybus extract $50 \mu \mathrm{l}, \mathrm{Cl} 75=\mathrm{C}$. intybus extract $75 \mu \mathrm{l}, \mathrm{Cl}$ $100=C$. intybus extract $100 \mu \mathrm{l}, \mathrm{Cl} 50+\mathrm{CS} 200=C$. intybus extract $50 \mu \mathrm{l}+\mathrm{C}$. sinensis extract $200 \mu \mathrm{l}$. Data are expressed in mean \pm S.E.M (standard error of the mean). " ${ }^{* * * \prime}$ means $p<0.01,{ }^{\prime * * * *}$ means $p<0.001$. $\mathrm{n}=7$ mice/group.

in serum's CAT levels. The delivering of C. intybus extract was at doses $(50 \mu \mathrm{l}, 75 \mu \mathrm{l}$ and $100 \mu \mathrm{l})$ and an association of C. intybus extract with C. sinensis at doses $(50 \mu \mathrm{l}+200 \mu \mathrm{l}$, respectively) resulted in an important increase in serum CAT activity. The percentage of CAT serum's levels increase for the dose CI extract $50 \mu \mathrm{l}$ was $30.11 \%$, for the dose of CI extract $75 \mu \mathrm{l}$ was $53.34 \%$, for the dose of CI extract $100 \mu \mathrm{l}$ was $66.96 \%$ and finally for the dose of CI extract $50 \mu \mathrm{l}+\mathrm{CS} 200 \mu \mathrm{l}$ was $64.76 \%$ when compared to DC.

\section{Management of diabetic neuropathy}

Diabetic patients with peripheral neuropathy possess an important indicator which is the decrease in the peripheral nerve conduction. On the $8^{\text {th }}$ week of the onset of the management of in alloxinated animals, we examined the effect of $C$. intybus extract alone at doses $(50 \mu \mathrm{l}, 75 \mu \mathrm{l}$ and $100 \mu \mathrm{l})$ and an association of $C$. intybus extract with $C$. sinensis extract at doses $(50 \mu \mathrm{l}+200 \mu \mathrm{l}$, respectively) on peripheral function by evaluating the thermal latency with HP test and TF and sensitivity to a mechanical stimulus by VFF. The results in the Figure 5 show a noticeable improvement in the thermal latency when compared to DC group which showed a temporary hyperalgesic response in the HP test. The percentage of improvement in the thermal latency (Hot Plate Latency) for the dose CI extract $50 \mu \mathrm{l}$ was $25.25 \%$, for the dose of CI extract $75 \mu \mathrm{l}$ was $43.29 \%$, for the dose of CI extract $100 \mu \mathrm{l}$ was $80.30 \%$ and finally for the dose of CI extract $50 \mu \mathrm{l}+\mathrm{CS} 200 \mu \mathrm{l}$ was $57.73 \%$ when compared to DC.

The results in the Figure 6 show a noticeable improvement in the thermal latency (TF Latency) when compared to vehicle-treated groups which showed a temporary hyperalgesic response in the TF test. The percentage of improvement in the thermal latency (Tail Flick Latency) for the dose CI extract $50 \mu \mathrm{l}$ was $32.77 \%$, for the dose of CI extract $75 \mu \mathrm{l}$ was $46.11 \%$, for the dose of CI extract $100 \mu \mathrm{l}$ was $92.22 \%$ and finally for the dose of CI extract $50 \mu \mathrm{l}+\mathrm{CS} 200 \mu \mathrm{l}$ was $83.88 \%$ when compared to DC.

The sensitivity to a mechanical stimulus using VFF was improved markedly on the week eight after the onset of the drug administration of alloxinated animals Figure 7. The improvement in the tactile allodynia for the dose CI extract $50 \mu \mathrm{l}$ was 11.58 folds, for the dose of CI extract $75 \mu \mathrm{l}$ was 14.16 folds, for the dose of CI extract $100 \mu \mathrm{l}$ was 23.48 folds

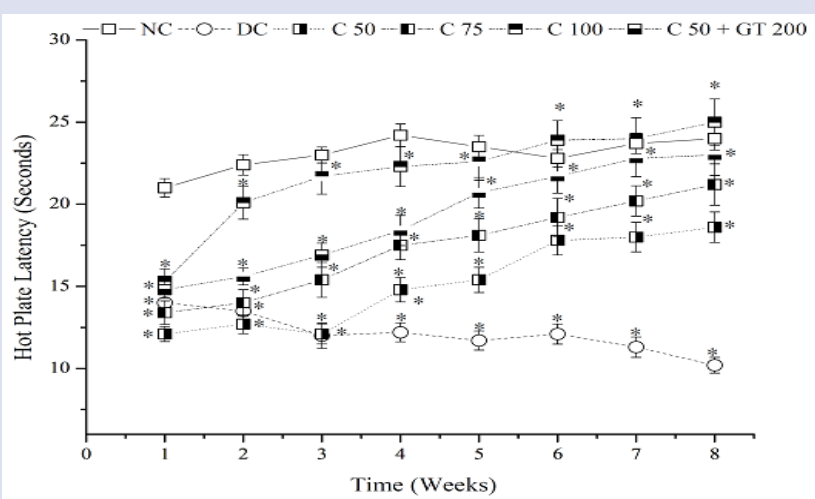

Figure 5: Effect of $C$. intybus on the hot plate latency in alloxaninduced diabetic mice. $\mathrm{NC}=$ Normal control, $\mathrm{DC}=$ Diabetic control, $\mathrm{Cl} 50=$ C. intybus extract $50 \mu \mathrm{l}, \mathrm{Cl} 75=$ C. intybus extract $75 \mu \mathrm{l}$, $\mathrm{Cl} 100=C$. intybus extract $100 \mu \mathrm{l}, \mathrm{Cl} 50+\mathrm{CS} 200=C$. intybus extract 50 $\mu \mathrm{l}+$ C. sinensis extract $200 \mu \mathrm{l}$. Data are expressed in mean \pm S.E.M (standard error of the mean). ${ }^{\prime * \prime \prime}$ means $p<0.05 . n=7$ mice/group.

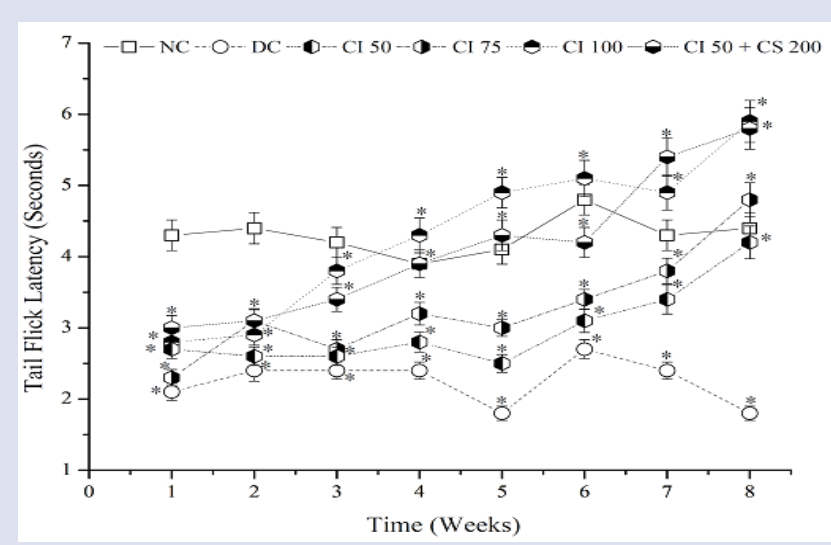

Figure 6: Effect of $C$. intybus on the tail flick latency in alloxan-induced diabetic mice. $\mathrm{NC}=$ Normal control, $\mathrm{DC}=$ Diabetic control, $\mathrm{Cl} 50=\mathrm{C}$. intybus extract $50 \mu \mathrm{l}, \mathrm{Cl} 75=\mathrm{C}$. intybus extract $75 \mu \mathrm{l}, \mathrm{Cl} 100=\mathrm{C}$. intybus extract $100 \mu \mathrm{l}, \mathrm{Cl} 50+\mathrm{CS} 200=C$. intybus extract $50 \mu \mathrm{l}+\mathrm{C}$. sinensisextract $200 \mu$ l. Data are expressed in mean \pm S.E.M (standard error of the mean). "**" means $p<0.05 . n=7$ mice/group.

and finally for the dose of CI extract $50 \mu \mathrm{l}+\mathrm{CS} 200 \mu \mathrm{l}$ was 18.90 folds when compared to DC.

\section{Histology results of mice's pancreas (diabetic mice)}

The histological sections have to be stained with $\mathrm{H}$ and $\mathrm{E}$ stain (Hematoxylin and eosin stain). Staining of the cells' components gives them a bright color, together with a counterstain that stains the rest of the cell a different color. The resulting colors are Nuclei, violet; muscle, pink; cytoplasm, pink; basophilic, blue; acidophilic, pink.

The following images are the results of the histology of NC, DC and the treated mice. The Figure 8 shows: In A. is the result of the pancreas' histology for NC: $\beta$ cells are $73.46 \%$. In B. pancreas' histology for DC: we see a decrease in $\beta$ cells to $23.80 \%$. In C. pancreas' histology for the one treated by $(\mathrm{CI}$ extract $50 \mu \mathrm{l})$ : we see an increase in $\beta$ cells to $30.61 \%$. In D. pancreas' histology for the one treated by (CI extract $75 \mu \mathrm{l})$ : we see an increase in $\beta$ cells to $40.81 \%$. In E. pancreas' histology for the one treated 


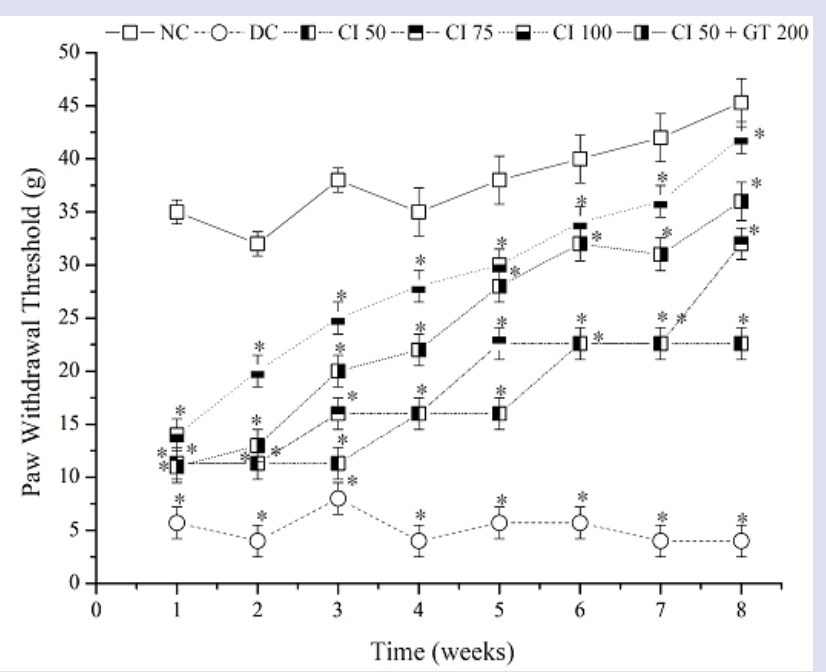

Figure 7: Effect of $C$. intybus on sensitivity to a mechanical stimulus in neuropathic model in alloxinated animals. Paw withdrawal thresholds to Von Frey Filaments were determined on hind paw up to 8 weeks after IP injection of $C$. intybus. NC = Normal control, DC = Diabetic control, $\mathrm{Cl} 50=\mathrm{C}$. intybus extract $50 \mu \mathrm{l}, \mathrm{Cl} 75=\mathrm{C}$. intybus extract $75 \mu \mathrm{l}, \mathrm{Cl}$ $100=C$. intybus extract $100 \mu \mathrm{l}, \mathrm{Cl} 50+\mathrm{CS} 200=C$. intybus extract $50 \mu \mathrm{l}+$ C. sinensis extract $200 \mu$ l. Data are expressed in mean \pm S.E.M (standard error of the mean). ${ }^{\mu *}$ "means $p<0.05 . \mathrm{n}=7$ mice/group.

by $(\mathrm{CI}$ extract $100 \mu \mathrm{l})$ : we see an increase in $\beta$ cells to $69.04 \%$. In F. pancreas' histology for the one treated by $(\mathrm{CI}$ extract $50 \mu \mathrm{l}+\mathrm{CS}$ extract $200 \mu \mathrm{l})$ : we see an increase in $\beta$ cells to $65.30 \%$.

\section{DISCUSSION}

The evaluation of the effect of DM, one of the oldest metabolic disorder known, is characterized as an endocrine disorder leading to an impairment of insulin secretion or insulin shortage that leads to an imbalance of glucose metabolism. Several factors or causes complicate the management of DM..$^{22}$ According to statistics done by the International Diabetes Federation, the total adult population per 1,000 of Lebanese between the ages of 20 and 79, is 3,801 with the prevalence of diabetes in adults being $12.2 \%$. The Number of deceases in grownups due to hyperglycemia is $5,723.80$. The budget of the person with hyperglycemia is $\$ 870.2{ }^{23}$

The common side effect of insulin injection is hypoglycemia. Symptoms comprise of headaches, hunger, faintness, sweating, tremors, irritability, trouble with concentration, shortness of breath, rapid heartbeats, collapsing, or seizures (severe hypoglycemia can be fatal). ${ }^{24}$ Also, there are possible side effects of diabetes medications. The Sulfonyl ureas' side effects are a drop in blood sugar, an irritated stomach, allergies and an increase in body weight. The Biguanides/Metformin's side effects are weight loss, alcohol sickness, kidney problems, an irritated stomach, exhaustion or faintness, metal taste. The Alpha-glucosidase inhibitors' side effects are gas, bloating and diarrhea. The Thiazolidinediones' side effects are weight gain, the risk of liver disease, anemia risk, inflammation of legs or ankles. The Meglitinides's side effects are weight gain, low blood sugar. ${ }^{24}$

All these side effects sited previously made the discovery of hypoglycemic agents with minimal or no adverse effects, the challenge. For a long time, only few plants, among many, have demonstrated that they are useful in the management of DM and have hypoglycemic activity. The use of
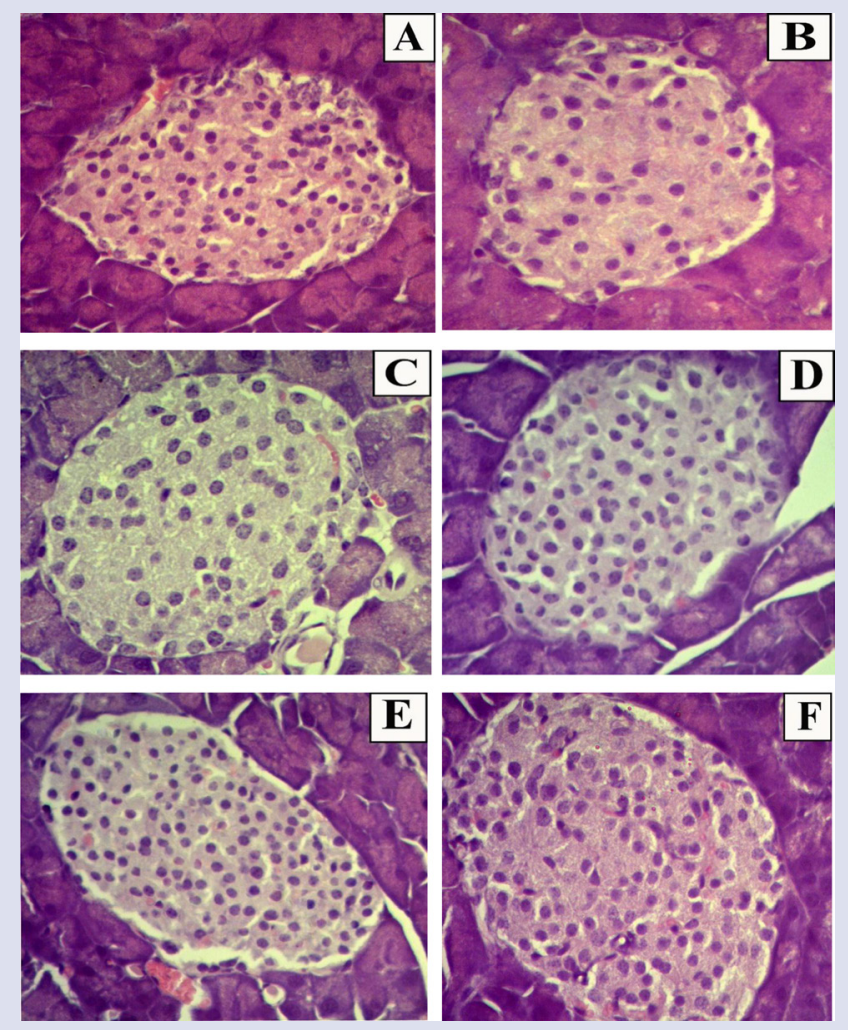

Figure 8: Figures 8 A- 8 F: A. Histology of the pancreas in Normal Control: $\beta$ cells are $73.46 \%$. B. Histology of the pancreas in Diabetic Control: $\beta$ cells are $23.80 \%$. C. Histology of the mouse's pancreas treated by $(\mathrm{Cl}$ extract $50 \mu \mathrm{l}): \beta$ cells are $30.61 \%$. D. Histology of the mouse's pancreas treated by $(\mathrm{Cl}$ extract $75 \mu \mathrm{l})$ : $\beta$ cells are $40.81 \%$. E. Histology of the mouse's pancreas treated by $(\mathrm{Cl}$ extract $100 \mu \mathrm{l})$ : $\beta$ cells are $69.04 \%$. F. Histology of the mouse's pancreas treated by $(\mathrm{Cl}$ extract $50 \mu \mathrm{l}+\mathrm{CS}$ extract $200 \mu \mathrm{l})$ : $\beta$ cells are $65.30 \%$.

complementary and alternative medications was admitted to be used by $30 \%$ of the patients. ${ }^{25}$

C. intybus hexane extract TLC revealed the presence of fructose, glucose and sucrose, ketose, nystose and the inulin type DP fructans: DP4, DP5 and DP6.

The chromatographic standardization of $C$. intybus extract, using isocratic HPLC, indicated that the abundant composites are available in the extract. The analysis of the sample revealed the presence of six peaks, which represent a total percentage of $92.22 \%$. The major compounds found in C. intybus extract are Chicoric acid at a high percentage $(64.70 \%)$, Isochlorogenic acid $\mathrm{A} / \mathrm{B} / \mathrm{C}(8.90 \%)$, Dicaffeoylquinic acid (6.87\%), Chlorogenic acid (4.81\%), Esculetin (3.54\%), Caffeic acid (3.40\%).

According to Pushparaj et al. ${ }^{13}$ had conducted a study to investigate the hypoglycemic effect of a C. intybus ethanolic extract. The extract is extensively prepared in India as a conventional drug for the management of DM. Hypoglycemic effects of C. intybus extracts were perceived in an oral glucose tolerance test (OGTT) that encourages the conventional faith that $C$. intybus might improve hyperglycemia. In a study conducted by haidari et al. ${ }^{26}$ results clearly showed that the oral administration of Camellia sinensis extract at a quantity of $200 \mathrm{mg} / \mathrm{Kg}$ improved the BGL. The BGL reached the normal levels in rats. The researchers suggested that EGCG (epigallocatechin gallate), one of the catechins in Camellia sinensis, enhances the oral glucose tolerance in severely diabetic mice. ${ }^{13}$ 
C. intybus extract was tested alone using the following doses, CI $50=C$. intybus extract $50 \mu \mathrm{l}, \mathrm{CI} 75=\mathrm{C}$. intybus extract $75 \mu \mathrm{l}$, CI $100=C$. intybus extract $100 \mu \mathrm{l}$ and in combination with C. sinensis CI $50+\mathrm{CS}$ $200=C$. intybus extract $50 \mu \mathrm{l}+C$. sinensis extract $200 \mu \mathrm{l}$. The dose of the C. intybus extract and C. sinensis extract was adjusted after many trials on different doses that most of them led to mice's dying from hypoglycemia. The latter dose was found to be the most appropriate.

DM was induced in the mouse by alloxan according to Raafat and Samy ${ }^{27}$ ${ }^{29}$ and Raafat and El-Lakany. ${ }^{27}$ The results showed successful induction of DM based on the rise in blood glucose to $(208.50 \pm 5.50 \mathrm{mg} / \mathrm{dl})$ and HbAlc levels $(8.50 \pm 0.43 \mathrm{mg} / \mathrm{dl})$ in mice alloxinated animals coupled with the failure of the mice to gain weight. The results are explained in the following paragraphs. ${ }^{19}$

The acute effect of $C$. intybus extract on BGL of alloxinated animals showed an important hypoglycemic effect and dose dependent effects on diabetic mice (Table 3 ). The hypoglycemic effect was more promising over longer periods. After $6 \mathrm{~h}$ post administration of the drug at doses $(50 \mu \mathrm{l}, 75 \mu \mathrm{l}, 100 \mu \mathrm{l})$ and $(50 \mu \mathrm{l}+200 \mu \mathrm{l})$ the decrease of blood glucose levels (BGL) was $14.15 \%$ significant at $(p<0.05), 19.69 \%, 42.4 \%$ and $35.19 \%$ and they are all significant at $(p<0.01)$, respectively; furthermore, the doses $(100 \mu \mathrm{l})$ and $(50 \mu \mathrm{l}+200 \mu \mathrm{l})$ were the most effective doses in lowering mice blood glucose levels (BGL).

The Subchronic effect of C. intybus extract on BGL of alloxan-induced diabetic mice showed a more important hypoglycemic effect (Table 4). The results showed dose dependent effects of $C$. intybus alone and in combination with $C$. sinensis. After 8 days of the starting of drug administration, at the doses $(50 \mu \mathrm{l}, 75 \mu \mathrm{l}, 100 \mu \mathrm{l})$ and $(50 \mu \mathrm{l}+200 \mu \mathrm{l})$ the decrease of blood glucose levels (BGL) was $23.41 \%, 25.39 \%, 44.8 \%$ and $39.35 \%$, respectively. All the dosages were statistically significant at $(\mathrm{p}<0.05)$; furthermore the doses $(100 \mu \mathrm{l})$ and $(50 \mu \mathrm{l}+200 \mu \mathrm{l})$ were the most effective doses in lowering mice blood glucose levels (BGL).

The sub-chronic effect of $C$. intybus extract on BW in alloxinated animals showed on the $8^{\text {th }}$ day an increase in the percentage of body weight when compared to DC. The results showed dose dependent effects of $C$. intybus alone and in combination with C. sinensis on DM. The percentage of body weight increase for the doses $(50 \mu \mathrm{l}, 75 \mu \mathrm{l}, 100 \mu \mathrm{l})$ and $(50 \mu \mathrm{l}+200 \mu \mathrm{l})$ was $6 \%, 8.5 \%$ (significant, at $(p<0.05), 14.2 \%$ and $15 \%$ (significant at $(p<0.01)$, respectively, when compared to DC $(28.45 \pm 0.45)$ and NC weight $(30.05 \pm 0.05)$. All these weights elevations reflect the amelioration of hyperglycemia as demonstrated previously with other DM phytotherapies. ${ }^{28}$

The glycated hemoglobin (HbA1c) was set as a principal of diagnosing criteria for DM ( $\geq 6.5 \%)$ and pre-diabetes (5.7-6.4\%) by the 2010 American Diabetes Association (ADA) principles of maintenance for hyperglycemic, founded mainly on the judgment of an international expert committee. ${ }^{29}$ HbAlc, measured 8 weeks after dose administration to diabetic mice, showed dose dependent effects of $C$. intybus alone and in combination with C. sinensis. For each group, $\mathrm{HbAlc}$ was measured to indicate the long-term hyperglycemia in mice. For the doses $(50 \mu \mathrm{l}, 75 \mu \mathrm{l}, 100 \mu \mathrm{l})$ and $(50 \mu \mathrm{l}+200 \mu \mathrm{l})$, HbAlc was $(7.3 \% \pm 0.37),(6.9 \% \pm 0.35),(6.27 \%$ $\pm 0.32)$ and $(6.5 \% \pm 0.33)$ when compared to DC group $(8.5 \% \pm 0.43)$. Although the four different doses have shown significant, at $(p<0.05)$, $\mathrm{HbAlc}$ reductions, the highest reduction was observed with CI extract $100 \mu \mathrm{l}$, with an $\mathrm{HbAlc}$ value of $(6.27 \% \pm 0.32)$. These doses were effective and maintained the HbAlc within the "good control" range. These results could be an evidence of the good glycemic control that CI extract alone and in combination with CS extract possess.

An isocratic HPLC of insulin was conducted to study the percentage of insulin in the nine groups of mice. The insulin was measured, 8 weeks after dose administration to diabetic mice. The level of insulin was dose dependent effects of $C$. intybus alone and in combination with
C. sinensis. The administration of the doses $(50 \mu \mathrm{l}, 75 \mu \mathrm{l}, 100 \mu \mathrm{l})$ and $(50 \mu \mathrm{l}+200 \mu \mathrm{l})$ showed an elevation of $(1.87 \% \pm 0.17)$ (significant at $(p<0.01),(3.22 \% \pm 0.16),(9.06 \% \pm 0.3)$ and finally $(7.94 \% \pm 0.39)$ (significant at $(p<0.001)$, respectively. The highest "Insulin" rates were with the doses $100 \mu \mathrm{l}$ and $(50 \mu \mathrm{l}+200 \mu \mathrm{l})$, respectively, when compared to $\mathrm{DC}(0.87 \% \pm 0.13)$.

The diabetic state is postulated in the rise of oxidative stress. In vivo, a disproportion in antioxidant enzyme, Catalase (CAT), has been related to the increase of DM complications. The higher the oxidative stress, the lower the CAT and the greater the incidence of DM. Rising CAT causes oxidative stress to decrease, contributing to the control of diabetes. $\beta$-cells have the strong sensitivity to oxidative stress, leading to the death and to the development, of type 1 diabetes. This effect was decreased by antioxidants. Antioxidants have shown promise effects to prevent and to be helpful for treating diabetes and its complications. ${ }^{30}$

CAT serum's levels, of each mice group, were measured 8 weeks after dose administration to diabetic mice. The results show dose dependent effects of $C$. intybus alone and in combination with C. sinensis. The administration of the doses $(50 \mu \mathrm{l}, 75 \mu \mathrm{l}$ and $100 \mu \mathrm{l})$ and $(50 \mu \mathrm{l}+200$ $\mu \mathrm{l})$, showed an increase in CAT's levels (30.11\%) (Significant, at $(p<0.01$, $53.34 \%, 66.96 \%$ and $64.76 \%$ (Significant, at $(p<0.001$ ), respectively, when compared to DC. Different doses of $C$. intybus alone and in combination with C. sinensis showed equi-potent antioxidant activity, which may indicate that the antioxidant effect of $\mathrm{CI}$ extract alone and in combination with CS extract over longer periodare potent even at a low doses.

Diabetic patients with peripheral neuropathy possess an important indicator, a decrease in the peripheral nerve conduction. Eight weeks after the dose administration to diabetic mice, the effect of $C$. intybus extract was examined alone at doses $(50 \mu \mathrm{l}, 75 \mu \mathrm{l}$ and $100 \mu \mathrm{l})$ and with C. sinensis extract at doses $(50 \mu \mathrm{l}+200 \mu \mathrm{l}$, respectively). The test was done on peripheral function by evaluating the thermal latency with HP test and TF and sensitivity to a mechanical stimulus by VFF. The results of the administration of the previously cited doses have eased hypersensitivity to pain situations by comparison to the DC in mice. The tests demonstrated that the different doses administered were very active against heat hypersensitivity and TA in animal models of diabetic neuropathy. In addition, the anti-nociceptive effect was dose-dependent alleviations with the maximum reduction observed with the highest dose $(100 \mu \mathrm{l})$ and with the association of doses $(50 \mu \mathrm{l}+200 \mu \mathrm{l})$, respectively. Furthermore, the most active dose against tactile allodynia producing 23.48 folds and 18.90 folds improvement was following the administration of the doses $(100 \mu \mathrm{l})$ and $(50 \mu \mathrm{l}+200 \mu \mathrm{l})$ when compared to DC.

The histology of mice pancreas showed an increase in the percentage of the pancreatic $\beta$-cells in all treated groups of diabetic mice (Figure 8). The sub-chronic effect of the doses $(50 \mu \mathrm{l}, 75 \mu \mathrm{l}$ and $100 \mu \mathrm{l})$ and $(50 \mu \mathrm{l}$ $+200 \mu \mathrm{l}$ ) showed an increase of $30.61 \%, 40.81 \%, 69.04 \%$ and $65.30 \%$, respectively, when compared to DC $(23.80 \%)$ and reaching approximately the normal levels ( $\mathrm{NC}=73.46 \%$ ). The percentage of the pancreatic $\beta$-cells was dose dependent effects; furthermore, the most effective doses were $(100 \mu \mathrm{l})$ and $(50 \mu \mathrm{l}+200 \mu \mathrm{l}) .^{30-32}$

\section{CONCLUSION}

In the Arab world, Cichorium intybus is one of our traditional plants. Many studies have been conducted to investigate its therapeutic effects to prove the traditional uses. Our study investigated the n-hexane extract of Cichorium intybus roots, which revealed a promising anti-diabetic, diabetic neuropathy and antioxidant effect. This is the first study of the n-hexane extract of Cichorium intybus roots in Lebanon. Furthermore, the histological study and the potent antioxidant effect supported this postulation by amelioration of insulin levels and enhancement of pancreatic beta cells. 
Kanj, et al:: Cichorium intybus Phytochemical and Biological Investigations

Cichorium intybus extract was extracted using hexane solvent and a TLC and HPLC analysis were performed on the hexane extracted oil of Cichorium intybus roots. The results indicated the presence of fructose, glucose and sucrose, ketose, nystose and the inulin type DP fructans: DP4, DP5 and DP6. HPLC indicated that the most active compounds of the hexane-extracted oil of $C$. intybus are Chicoric acid at a high percentage (64.70\%), Isochlorogenic acid A/B/C (8.90\%), Dicaffeoylquinic acid (6.87\%), Chlorogenic acid (4.81\%), Esculetin (3.54\%), Caffeic acid (3.40\%).

All the demonstrated data revealed that the combination of both; the hexane-extract of Cichorium intybus and the aqueous extract of Camellia sinensis could assist in the management of many diseases including Diabetes Mellitus and diabetic neuropathy. Furthermore, the histological study and the potent antioxidant effect supported this postulation by amelioration of insulin levels and regeneration of pancreatic beta-cells.

\section{ACKNOWLEDGEMENT}

Authors are so grateful to Mrs. G. Onsy for English proof-reading the manuscript.

\section{CONFLICT OF INTEREST}

The authors declare no conflict of interest.

\section{ABBREVIATIONS}

ACN: Acetonitrile; BGL: Blood Glucose Levels; CI: Cichorium intybus; CAT: Serum catalase; DC: Diabetic Control; DDW: Double distilled water; DM: Diabetes mellitus; DMSO: Dimethyl sulfoxide; DN: Diabetic Neuropathy; NC: Normal control; S.E.M.: Standard error of the mean.

\section{REFERENCES}

1. Balamurugan K, Nishanthini A, Moha VR. Antidiabetic and antihyperlipidaemic activity of ethanol extract of Melastomamalabathricum Linn. leaf in alloxan induced diabetic rats. Asian Pac J Trop Biomed. 2014;4(1):S442-8.

2. Boukhris M, Bouaziz M, Feki I, Jemai H, El FekiA, Sayadi S. Hypoglycemic and antioxidant effects of leaf essential oil of Pelargonium graveolens L'Hér. In alloxan induced diabetic rats. Lipids in Health and Disease. 2012;11:81.

3. Qujeq D, Rezvani T. Catalase (antioxidant enzyme) activity in streptozotocininduced diabetic rats. Int J Diabetes and Metabolism. 2007;15:22-4.

4. Qujeq D, Rezvani T. Catalase (antioxidant enzyme) activity in streptozotocininduced diabetic rats. Int J Diabetes and Metabolism. 2007;15:22-24.

5. Flora SJS. Structural, chemical and biological aspects of antioxidants for strategies against metal and metalloid exposure. Oxidative Medicine and Cellular Longevity. 2009;2(4):191-206.

6. Liu X, Kokare $\mathrm{CH}$. Biotechnology of Microbial Enzymes. Production, Biocatalysis and Industrial Applications. Chapter 11 - Microbial Enzymes of Use in Industry. Academic Press. 2017;267-98.

7. Street RA, Sidana J, Prinsloo G. Review Article: Cichorium intybus: Traditiona Uses, Phytochemistry, Pharmacology and Toxicology. Evidence-Based Complementary and Alternative Medicine. 2013;(579319):13

8. Gol NR, Noghani RZ, Chamsaz M. A comparative study of the chemical composition and antioxidant activities of roots, seeds and aerial parts of chicory (Cichorium intybus L.). International Journal of Biosciences. 2014;5(12):250-7.

9. Francis F, Talhouk S, Batal M,Olabi A. Sensory and quality parameters of raw and processed Chicory-Hindbeh, a commonly consumed dark leafy green in Lebanon (Cichorium intybus L.) during frozen storage. LWT - Food Science and Technology. 2014;58(2014):230-8.

10. Judžentiene A, Budiene J. Volatile constituents from aerial parts and roots of Cichorium intybus L. (chicory) grown in Lithuania. Chemija. 2008;19(2):25-8.

11. Shaikh T, Mujum A, Wasimuzzama K, Rub RA. An Overview on Phytochemical and Pharmacological Profile of Cichorium intybus Linn. Pharmacology Online. 2010;2:298-307.

12. Kim HM, Kim J. The Effects of Green Tea on Obesity and Type 2 Diabetes.
Diabetes and Metabolism Journal. 2013;37(3):173-5. http://doi.org/10.4093/ dmj.2013.37.3.173

13. Pushparaj PN, Low HK, Manikandan J, Tan BKH, Tan CH. Anti-diabetic effects of Cichorium intybus in streptozotocin-induced diabetic rats. Journal of Ethnopharmacology. 2007;111(2):430-4.

14. Koner A, Ghosh S, Roy P. Isolation of Antimicrobial Compounds from Chicory (Cichorium intybus L.) Root. International Journal of Research in Pure and Applied Microbiology. 2011;1(2):13-8.

15. Raafat K, Aboul-Ela M, El-Lakany A. Alloxan-induced diabetic thermal hyperalgesia, prophylaxis and phytotherapeutic effects of Rheum ribes $\mathrm{L}$. in mouse model. Archives of Pharmacal Research. 2014;1-10.

16. Raafat K, Smay W. Amelioration of diabetes and painful diabetic neropathy by Punicagranatum L. Extract and its spray dried bioploymeric dispersions. Evidence-Based Complementary and Alternative Medicine. 2014.

17. Raafat K, Aboul-Ela M, El-Lakany A. Alloxan-induced diabetic thermal hyperalgesia, prophylaxis and phytotherapeutic effects of Rheum ribes $L$. in mouse model. Archives of Pharmacal Research. 2014;1-10.

18. Raafat K, Smay W. Amelioration of diabetes and painful diabetic neropathy by Punicagranatum L. Extract and its spray dried bioploymeric dispersions Evidence-Based Complementary and Alternative Medicine. 2014.

19. Cichorium intybus (root). Cited on Jun 24, 2015. 2015.Available from: http:// www.botanicalauthentication.org/index.php/Cichorium_intybus_(root)

20. Sakamoto HT, Gobbo-Neto L, Cavalheiro AJ, Lopes NP, Lopes JL. Quantitative HPLC analysis of sesquiterpene lactones and determination of chemotypes in Eremanthusseidelii MacLeish and Schumacher (Asteraceae). Journal of the Brazilian Chemical Society. 2005;16(6B):1396-401.

21. Ulugol A, Oltulu C, Gunduz O, Citak C, Carrara R, Shaqaqi MR, et al. 5-HT7 receptor activation attenuates thermal hyperalgesia in streptozocin-induced diabetic mice. Pharmacology Biochemistry and Behavior. 2012;102(2):344-8.

22. Bonin RP, Bories C, De Koninck Y. A simplified up-down method (SUDO) for measuring mechanical nociception in rodents using von Frey filaments. Molecular Pain. 2014;10(1):26.

23. Yasmineh WG, Kaur TP, Blazar BR, Theologide A. Serum Catalase as Marker of Graft-vs-Host Disease in Allogeneic Bone Marrow Transplant Recipients: Pilot Study. CLIN CHEM. 1995;41(11):1574-80.

24. Martins JLR, RodriguesORL, da Silva DM, Galdino PM, de Paula JR, Romão W, et al. Mechanisms involved in the gastroprotective activity of Celtisiguanaea (Jacq.) Sargent on gastric lesions in mice. Journal of Ethnopharmacology. 2014;155(3):1616-24.

25. Lebanon. Lebanon vs World Prevalence of Diabetes. 2015. Available from: http://www.idf.org/membership/mena/lebanon

26. LANTUS (insulin glargine injection). Retrieved at 10/31/2017. 2017. Available from: https://www.rxlist.com/lantus-side-effects-drug-center.htm\#overview

27. Rajan M, Kumar VK, Kumar PS, Swathi KR, Haritha S. Antidiabetic, antihyperlipidaemic and hepatoprotective activity of methanolic extract of Ruellia tuberose Linn. leaves in normal and alloxan induced diabetes. J Chem Pharm Res. 2012;4:2860-8.

28. Haidari F, Omidian K, Rafiei H, Zarei M, Mohamad SM. Green Tea (Camellia sinensis) Supplementation to Diabetic Rats Improves Serum and Hepatic Oxidative Stress Markers. Iranian Journal of Pharmaceutical Research. 2013;12(1):109-14

29. Raafat K, El-Lakany A. Acute and subchronic in-vivo effects of Ferula hermonis L. and Sambucusnigra L. and their potential active isolates in a diabetic mouse model of neuropathic pain. BMC Complementary and Alternative Medicine. 2015;15(1):1.

30. Raafat K, Boukhary R, Aboul-Ela M, El-Lakany A. Endogenous Lebanese Plants Treating Diabetes and Related Complications. Nat Prod Chem Res. 2013;1(3):112-20.

31. American Diabetes Association. Diagnosis and Classification of Diabetes Mellitus. Diabetes Care. 2010;33(11):S62-9. Available from: http://doi.org/10.2337/ dc10-S062

32. Saleh MA, Clark S, Woodard B, Deolu-Sobogun SA. Antioxidant and Free Radical Scavenging Activities of Essential oils. Ethnicity and Disease. 2010;20(1):78-82.

\section{SUPPLEMENTARY MATERIALS}

Figure S1 and Figure S2 
GRAPHICAL ABSTRACT

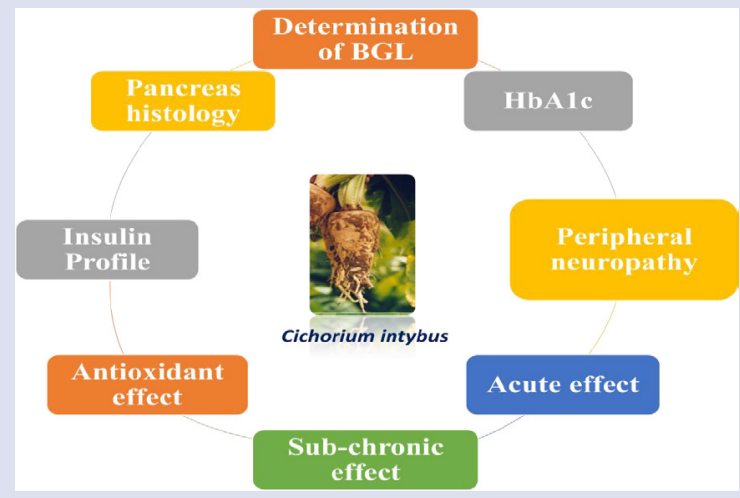

\section{SUMMARY}

- All the demonstrated data revealed that the combination of both the hexane extract of Cichorium intybus and the aqueous extract of Camellia sinensis can assist in the management of diabetes mellitus and diabetic neuropathy. Furthermore, the histological study and the potent antioxidant effect supported this postulation by amelioration of insulin levels and the regeneration of pancreatic $\beta$-cells.

\section{ABOUT AUTHORS}

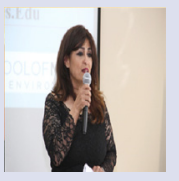

Dr. Safaa Baydoun is the director of the Research Centre for Environment and Development, Beirut Arab University, Taanayel, Lebanon. She has several publications and awards in the field of the environment and development.

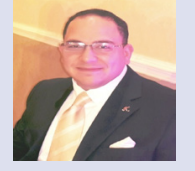

Dr. Karim M. Raafat is an Associate Professor of Phytochemistry and Pharmacognosy at Faculty of Pharmacy, Beirut Arab University. He has completed his PhD from German University in Cairo, New Cairo, Egypt, under the channel system and joint supervision scheme between The German University in Cairo (GUC) and Johann Wolfgang Goethe-University Frankfurt, Germany and postdoctoral studies from Beirut Arab University (BAU) and German University in Cairo. He is a visiting Scientist of Johann Wolfgang Goethe-University, Frankfurt, Germany. He is the Head of Phytochemistry Research Team and Junior Research Team, BAU, Lebanon. He has published more than seventy books, book chapters, patent and peer reviewed journal articles and presentations in scientific conferences. He has been honored with several national and international awards in the scientific field and public service.

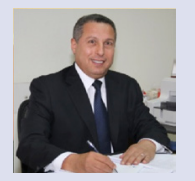

Prof. Abdalla El-Lakany is currently the Dean of Faculty of Pharmacy, Beirut Arab University. He has over 25 years of experience in teaching Phytochemistry, Pharmacognosy and Medicinal Plants and supervision of $\mathrm{PhD}$, Masters and Pharm.D. theses. He is specialized in chemistry of natural products, with a special interest in diterpenoids, alkaloids and flavonoids. He has attended many national and international conferences and supervising more than 20 Master, Pharm.D and PhD Theses. Currently, he has a research project about alkaloids and their biological testing. He has published more than 55 scientific articles in high-impact journals.

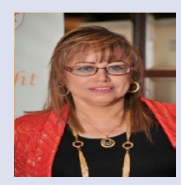

Prof. Maha Aboul-Ela is the Head of Pharmaceutical Sciences Department, Faculty of Pharmacy, Beirut Arab University. She has 30 years experience in teaching (under and post graduates courses) and research in Pharmacognosy and Phytochemistry and 7 years experience in the field of QA in Higher education. Distinguishable Peer Reviewer at Egyptian National Organization for QA and accreditation. She has published more than 50 research articles in national and international scientific journals in the field of specialization. Attending many national and international conferences. Supervising more than 14 Master, Pharm.D and PhD Theses. She had PhD mission to West Germany for completion of practical studies and postdoctoral mission to School of Pharmacy, University of London, UK. She has Membership in the American Society of Pharmacognosy and the Egyptian Pharmaceutical Society.

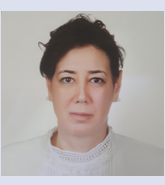

Dina Kanj is a M.Sc. holder from the Faculty of Pharmacy, Beirut Arab University (BAU) where she has graduated in Bachelor of Pharmaceutical Sciences and Master of Pharmacognosy and Medicinal Plants. Her Masters research focused on Phytopharmacological study of Cichorium intybus growing in Lebanon.

Cite this article: Kanj D, Raafat K, El-Lakany A, Baydoun S, Aboul-Ela M. Phytochemical Compounds Of Cichorium intybus by Exploring its Antioxidant and Antidiabetic Activities. Pharmacog J. 2019;11(2):248-57. 